Article

\title{
Detection and Mapping of Black Rock Coatings Using Hyperion Images: Sudbury, Ontario, Canada
}

\author{
David W. Leverington ${ }^{1, *}$ and Michael Schindler ${ }^{2}$ \\ 1 Department of Geosciences, Texas Tech University, Lubbock, TX 79409, USA \\ 2 Department of Earth Sciences, Laurentian University, Sudbury, ON P3E 2C6, Canada; \\ mschindler@laurentian.ca \\ * Correspondence: david.leverington@ttu.edu; Tel.: +1-806-834-5310; Fax: +1-806-742-0100 \\ Academic Editors: Richard Gloaguen and Prasad S. Thenkabail \\ Received: 29 November 2015; Accepted: 29 March 2016; Published: 2 April 2016
}

\begin{abstract}
Base metal smelting activities can produce acidic rain that promotes vegetation loss and the development of black coatings on bedrock. Such coatings can form over large areas and are among the most prominent long-term vestiges of past smelting activities. In this study, multispectral images derived from Hyperion reflectance data were evaluated with regard to their utility in the discrimination and mapping of black rock coatings near Sudbury. Spectral angle mapper (SAM) classifications generated on the basis of image-derived endmember spectra could not be used to properly identify major exposures of coated bedrock without also producing substantial confusion with uncoated classes. Neural network and maximum likelihood classifications produced improved representations of the spatial distribution of coated bedrock, though confusion between coated and uncoated classes is problematic in most outputs. Maximum likelihood results generated using a null class are noteworthy for their effectiveness in highlighting exposures of coated bedrock without substantial confusion with uncoated classes. Although challenges remain, classification results confirm the potential of remote sensing techniques for use in the worldwide detection, mapping, and monitoring of coating-related environmental degradation in the vicinities of base metal smelters.
\end{abstract}

Keywords: smelter; rock coating; classification; hyperspectral; Hyperion

\section{Introduction}

Black rock coatings can form in the vicinities of base metal smelters as a result of the interaction of smelter emissions with rock surfaces [1-4]. Though characterized by thicknesses no greater than several hundred micrometers, black rock coatings can persist for decades and are among the most prominent long-term vestiges of past smelting activities. Remote sensing techniques are potentially well suited for discrimination and mapping of exposed black rock coatings, and correspondingly may be helpful in highlighting areas most affected by past or ongoing environmental degradation resulting from smelting activities. The formation mechanisms of black rock coatings are similar to acid-sulfate processes that operate under natural conditions in regions of volcanic and hydrothermal activity [2,5-7], and the application of remote sensing techniques toward the discrimination of smelter-related coatings is thus relevant to the broader topic of the remote detection of acid-sulfate deposits. Problematically, discrimination of smelter-related black rock coatings can prove challenging as a result of the absence of distinctive features in the reflectance spectra of coatings [8].

The Sudbury region of Ontario, Canada, hosts world-class Ni-Cu-PGE (nickel, copper, platinum-group elements) mineralization that has been locally mined and processed since the 19th century [9]. Smelter-related environmental degradation, including development of black rock coatings, primarily occurred here over a period extending from the late 1880 's until the middle 1970 's $[10,11]$. Though formation of black rock coatings in the Sudbury region has now ceased as 
a result of smelter upgrades and closures, the widespread persistence of coatings here makes this region useful for evaluation of remote sensing techniques in the identification and mapping of these coatings. In this study, the utility of Hyperion images in the discrimination of black rock coatings was evaluated for two study areas in the Sudbury region (Figure 1). Multispectral databases derived from Hyperion data were classified for each study area using the spectral angle mapper (SAM), feedforward backpropagation neural network, and maximum likelihood algorithms. Classification results were evaluated through comparison of predicted coating distributions with known distributions of surface classes including coated bedrock.

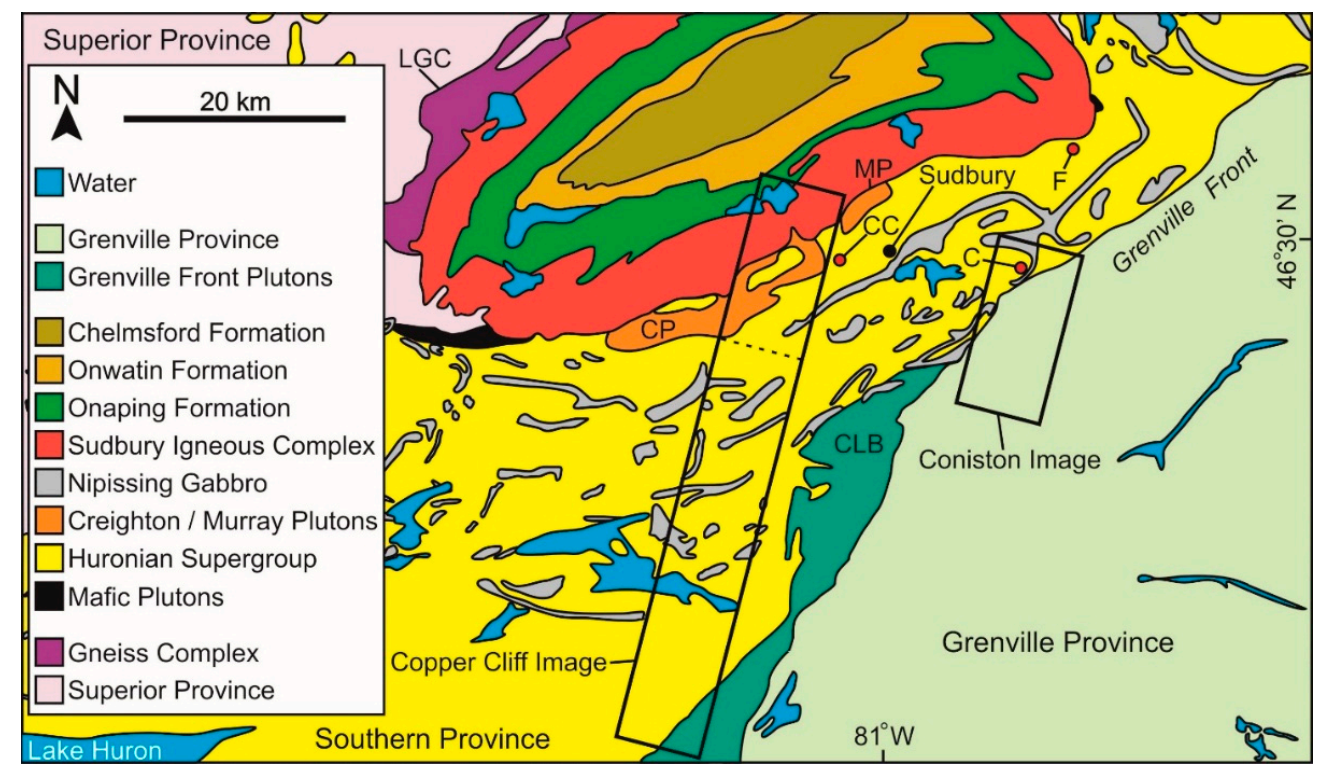

Figure 1. Bedrock geology of the Sudbury region (after $[8,10])$. Labelled intrusions are as follows: CLB, Chief Lake Batholith; CP, Creighton pluton; MP, Murray pluton; LGC, Levack gneiss complex. The locations of the Copper Cliff (CC), Coniston (C), and Falconbridge (F) smelter stacks are indicated by red circles. The footprints of utilized sections of the Copper Cliff and Coniston Hyperion images are given, and the extents of these footprints define the Copper Cliff and Coniston study areas. The dashed line associated with the Copper Cliff study area separates the main part of the study area (top) from the remainder of the study area (bottom).

\section{Black Rock Coatings near Sudbury Base Metal Smelters}

Base metal smelting activities can result in the release of particulate matter and of sulfuric acid and $\mathrm{SO}_{2}$ gas, all of which can be entrained by winds and distributed far beyond smelter stacks [2-4,12-14]. Sulfuric acid and oxidation of $\mathrm{SO}_{2}$ can result in precipitation events characterized by very low $\mathrm{pH}(<3)$. Acid rain of this nature can promote vegetation loss and cause dissolution of exposed siliceous minerals, producing a silica-gel type coating that can trap locally-derived detrital material and smelter-derived particulate matter. This coating ultimately hardens to form a black rock coating [2-4,14].

Black rock coatings in the Sudbury region (Figures 2 and 3) are generally less than $200 \mu \mathrm{m}$ in thickness and typically consist of: (1) a lower zone that consists of variably-weathered underlying rock; (2) a main zone that consists of opal-like amorphous $\mathrm{SiO}_{2}$ that acts as a matrix for both locally-derived and smelter-derived particulates; and (3) metal-sulfate-enriched zones that typically occur as thin layers either at the upper surface of the coating or between the underlying rock and the coating $[2,8]$. In the Sudbury region, smelter-derived particulate matter trapped in the silica-rich matrix consists largely of nanometer- to micrometer-sized spherical particulates composed of carbon soot, minerals of the spinel group, and high-temperature silicates such as minerals of the olivine and pyroxene groups $[2,3,15,16]$. Coatings here are found up to tens of kilometers from the sites of past smelting activities [8]. 

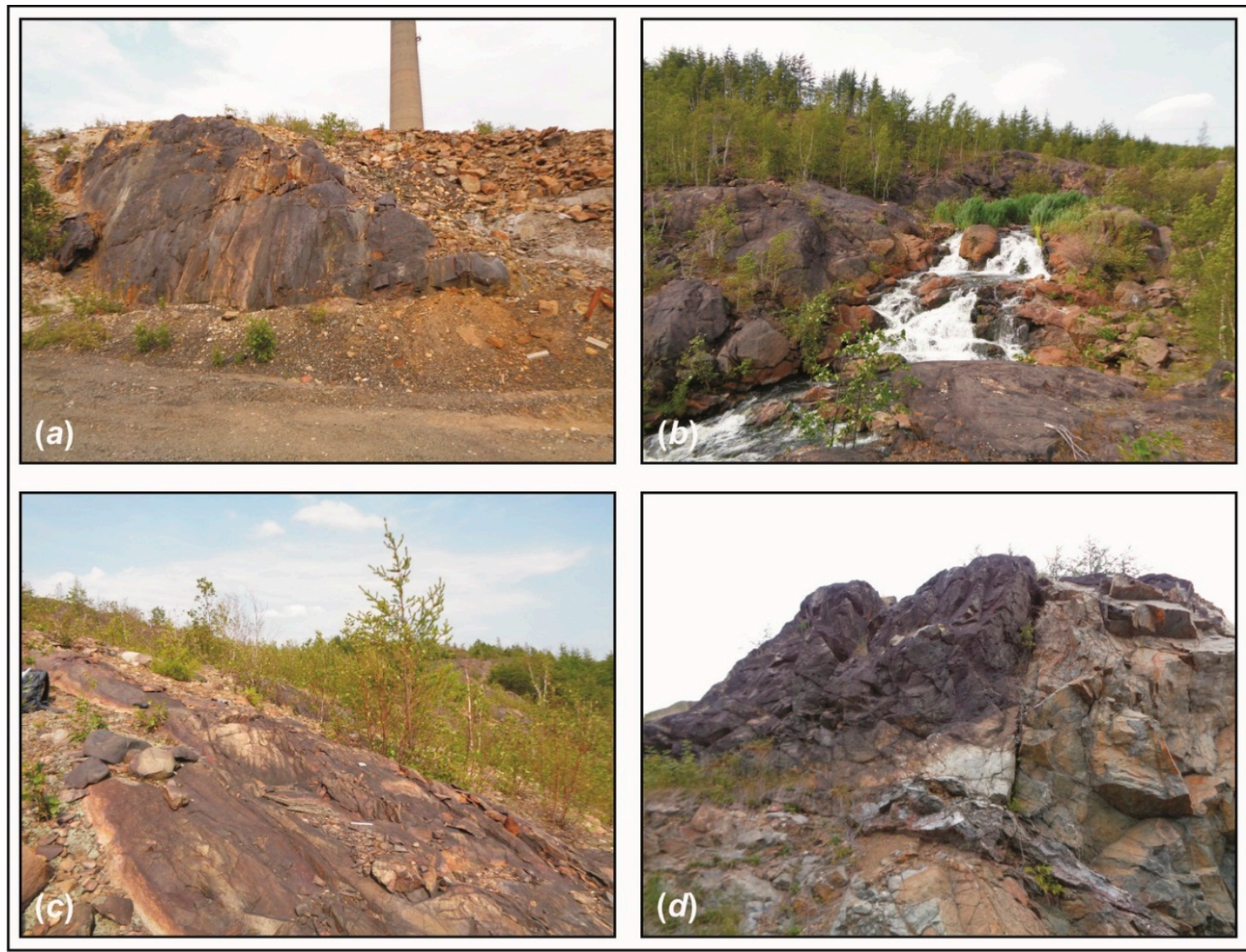

Figure 2. Examples of coated bedrock located in the Coniston study area: (a) Mississagi Formation, near the base of the south Coniston stack; (b) Grenville gneiss; (c) Mississagi Formation; (d) Nipissing Gabbro.

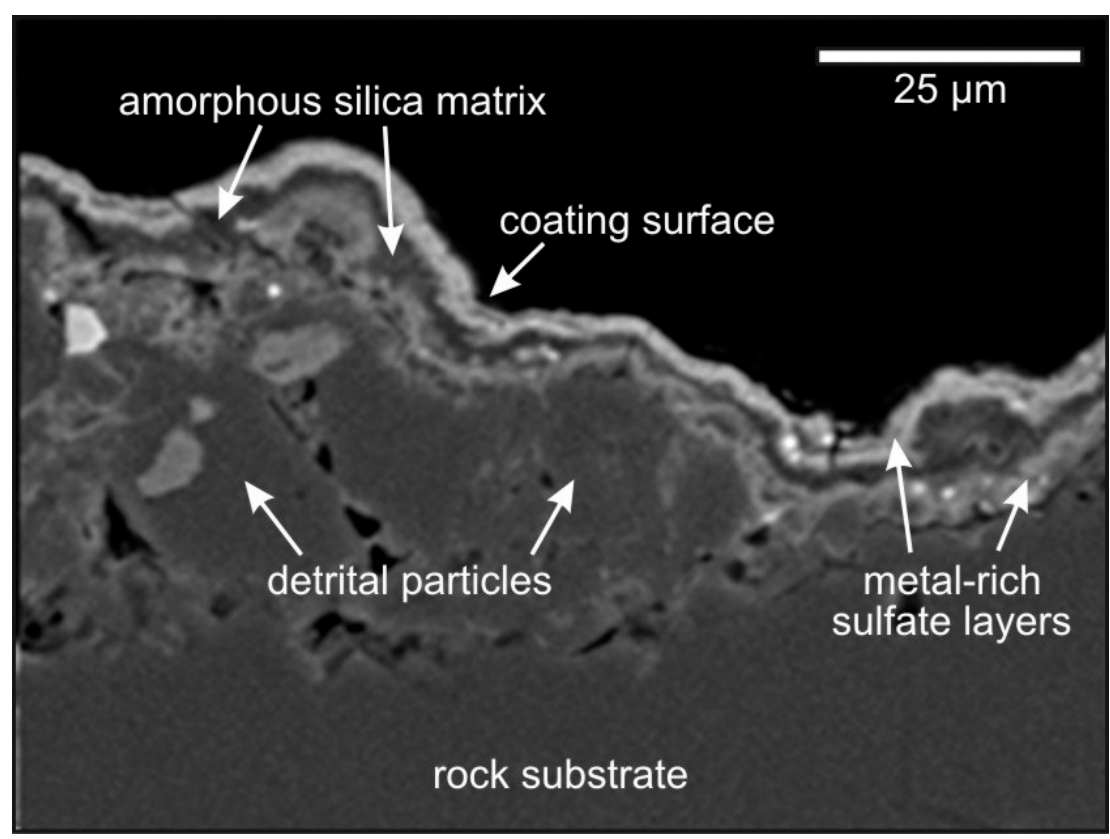

Figure 3. Scanning electron microscope image of a black rock coating associated with materials of the Copper Cliff Formation. 


\section{Remote Sensing of Black Rock Coatings near Smelters}

Remote sensing techniques have previously been used to identify areas of low vegetative cover in the vicinities of smelting and roasting operations [17-22], and to monitor changes in vegetation cover in areas of past and ongoing environmental degradation related to such operations [20,23-30]. Remote sensing techniques have also been used to more generally help highlight areas affected by past smelting activities [31], and to discriminate rocks and minerals in related mine tailings [32-37].

Recent attempts to discriminate and map black rock coatings in the Sudbury area on the basis of a Landsat ETM+ (Enhanced Thematic Mapper Plus) multispectral image produced mixed results [8]. In that work, a SAM-based classification using a lab-derived spectral endmember for the coating class was not successful, with a classification accuracy of only $21 \%$ and with numerous associated errors of commission. In contrast, maximum likelihood and feedforward backpropagation neural network classifiers generated coating maps with accuracies as great as $71 \%$ and with relatively few errors of commission.

\section{Sudbury Study Areas}

Sudbury is located northeast of Lake Huron and is underlain by Precambrian bedrock of the Superior, Southern, and Grenville provinces (Figure 1) [38-43]. Local bedrock consists of igneous, sedimentary, and impact units that have generally been metamorphosed to between greenschist and granulite facies [44-46]. Vegetation in the Sudbury region consists mainly of mixed deciduous boreal forest [47], though past logging, smelting, and roasting activities locally produced woodlands, savanna, and treeless barrens [23-25,48]. Topographic relief in the Sudbury region is under $250 \mathrm{~m}$, and sedimentary cover is mostly thin and discontinuous [31].

Thick black rock coatings in the Sudbury region are effective in inhibiting the spectral expression of underlying minerals (Figure 4). Though this attribute has the potential to facilitate the identification of coatings using remote sensing techniques, the absence of prominent spectral features in coating spectra can promote confusion between coatings and spectrally similar surface classes such as asphalt [8] (Figure 5). Extensively coated areas are typically characterized by relatively low levels of vegetation cover (Figure 6).
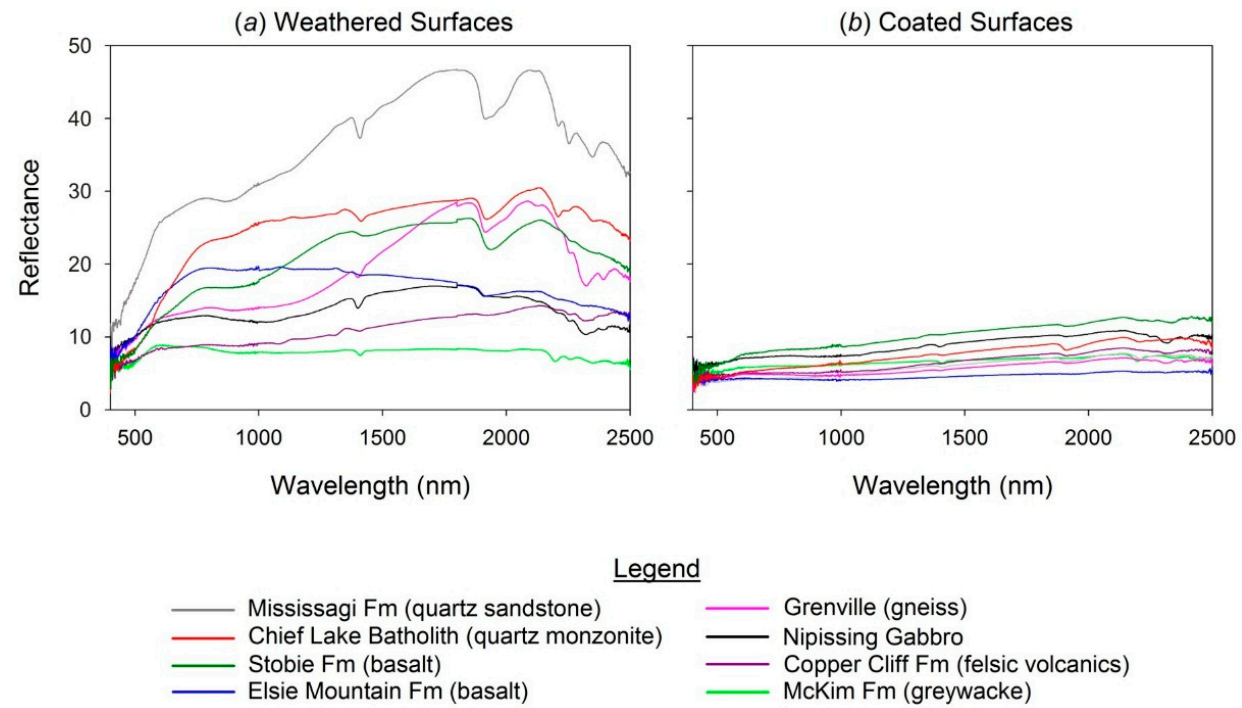

Figure 4. Sudbury bedrock units covered by black coatings are characterized by low albedo and an absence of prominent absorption features in reflectance spectra (after [8]): (a) weathered surfaces that are not coated; (b) coated surfaces. The above spectra are expressed as percentages and were measured at centimeter scale from Sudbury field samples over wavelengths of 400 to $2500 \mathrm{~nm}$ using a FieldSpec3 spectrometer equipped with a contact probe and integrated illumination source. 

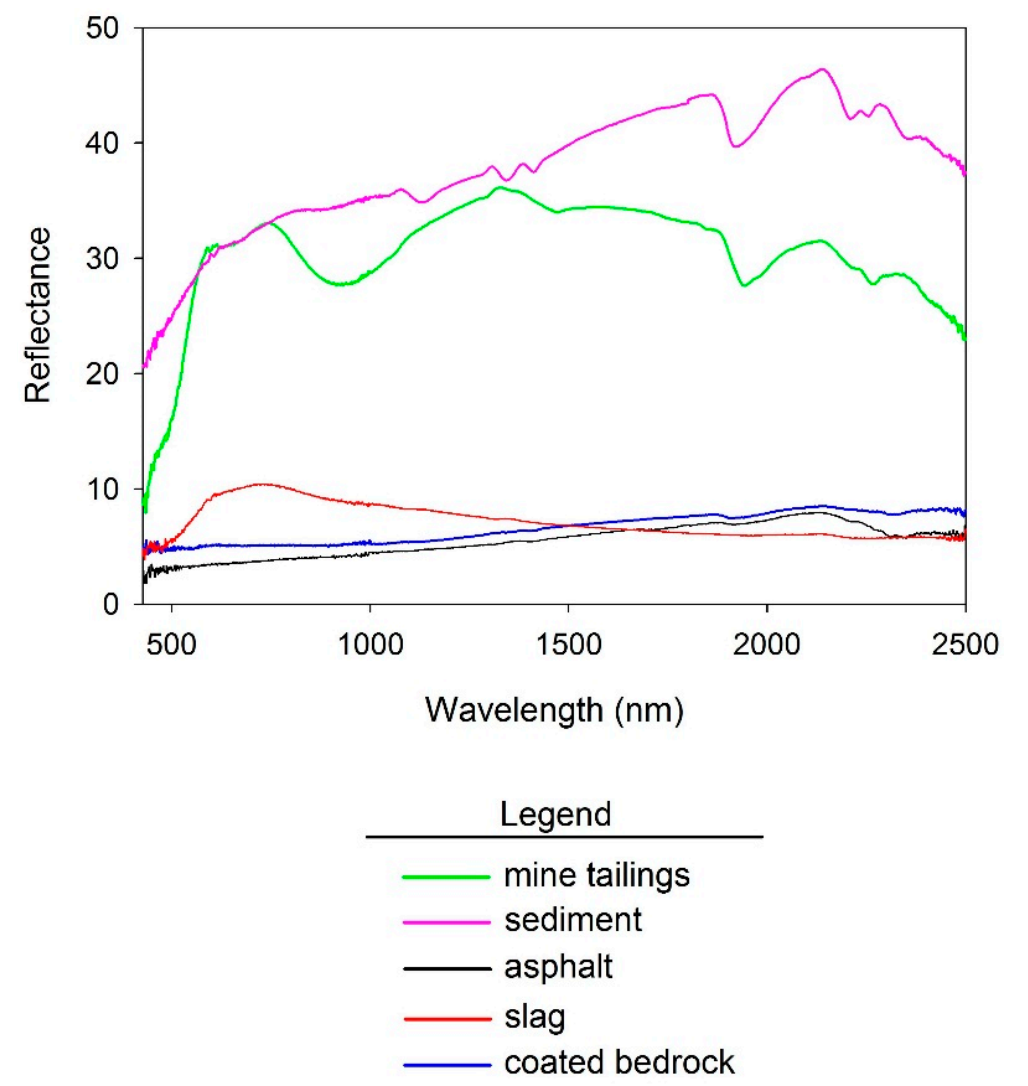

Figure 5. Comparison between lab-measured spectra obtained for tailings, sediment, asphalt, slag, and coated bedrock in the Sudbury region. The tailings spectrum is derived from a sample of materials associated with the main smelter in the Copper Cliff study area, the sediment spectrum is derived from a sample of materials exposed at the sediment pit marked "SP" in Figure 6c, the asphalt spectrum is derived from a sample of materials typical of paved roadways in the Sudbury region, the slag spectrum is derived from a sample collected at a Coniston slag heap, and the coated bedrock spectrum is derived from a coated sample of the Copper Cliff Formation. The above spectra are expressed as percentages and were measured at centimeter scale over wavelengths of 400 to $2500 \mathrm{~nm}$ using a FieldSpec3 spectrometer equipped with a contact probe and integrated illumination source.

The Copper Cliff study area (Figure 1) is mainly underlain by bedrock of the Southern Province. Bedrock exposure here is greatest near the Copper Cliff stacks, which have operated since the late 1880 's and which were upgraded in the 1970's, in part through construction of the $380 \mathrm{~m}$ "Inco Superstack" $[10,11]$. Much of the remainder of the study area is covered by boreal forest, though uncoated bedrock exposures exist in the southernmost part of the study area ("UB" in Figure 6a). Parts of the Copper Cliff study area that are located immediately west of the Copper Cliff smelter stacks consist of tailings deposits and tailings ponds (Figures $6 \mathrm{~b}$ and 7a). Tailings here are byproducts of local milling activities and consist of finely-ground concentrates discharged in the form of slurries into topographic basins [49]. Copper Cliff tailings are composed largely of minerals such as Fe-oxides, feldspars, amphiboles, quartz, and pyroxenes, but also contain high levels of metals and metalloids [50]. Tailings deposits exposed immediately north of and along the periphery of Meatbird Lake were active at the time of imaging, whereas tailings deposits located further to the east were inactive and had been subjected to varying levels of reclamation including revegetation [34,51]. Slag heaps related to the Copper Cliff smelter are located outside of the Copper Cliff study area, east of the tailings deposits depicted in Figure 6b. 

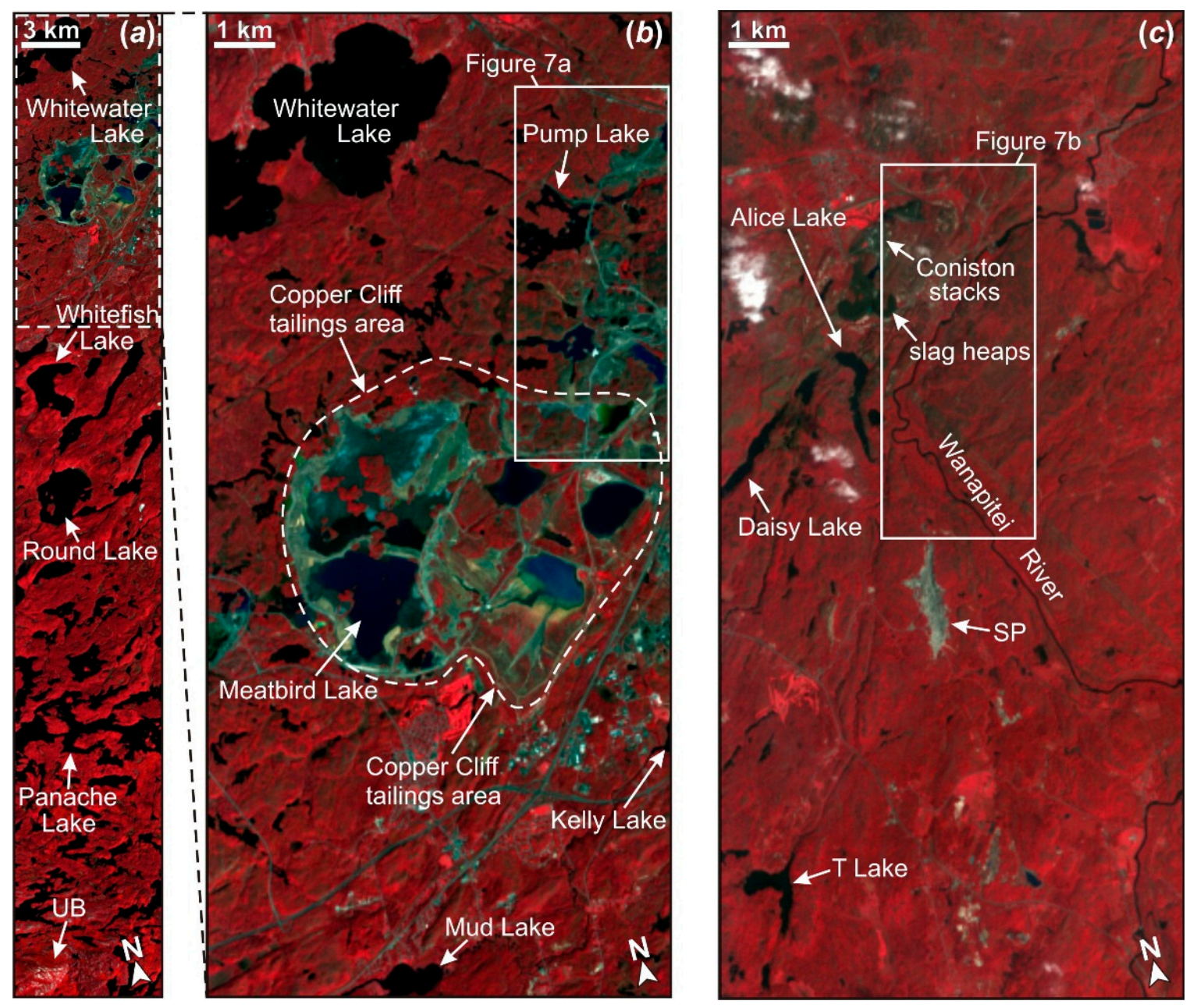

Figure 6. Hyperion hyperspectral data are available for areas near the Copper Cliff $(\mathbf{a}, \mathbf{b})$ and Coniston (c) smelters. The above images are Hyperion color-infrared composites (red = $753 \mathrm{~nm}$; green $=651 \mathrm{~nm}$; blue $=560 \mathrm{~nm}$ ) that highlight vegetative cover in shades of red. The outlines of areas depicted in the aerial orthophotos of Figure 7 are indicated. A prominent exposure of uncoated bedrock in the southernmost part of the Copper Cliff study area (a) is labeled "UB", and a large sediment pit in the central part of the Coniston study area (c) is labeled "SP". Cloud cover is present in the northern half of the Coniston study area (white irregularly-shaped patches). Image footprints and smelter stack locations are given in Figure 1.

The Coniston study area (Figure 1) is underlain by bedrock of the Southern and Grenville provinces. As with the Copper Cliff study area, the Coniston study area is largely covered by boreal forest. Bedrock exposure here remains greatest near the Coniston stacks, which were closed in the 1970 's after nearly 60 years of operation [25,52]. Most of these exposures are at least partly coated, and uncoated bedrock is relatively rare in the Coniston study area at the $30 \times 30 \mathrm{~m}$ pixel sizes of Hyperion images. Slag heaps are located south of the Coniston stacks and also underlie parts of the Coniston airfield (Figures $6 \mathrm{c}$ and $7 \mathrm{~b}$ ). Tailings deposits are present but are not widely exposed in the Coniston study area. A large sediment pit unrelated to past milling and smelting activities is located in the south-central part of the study area ("SP" in Figure 6c). 

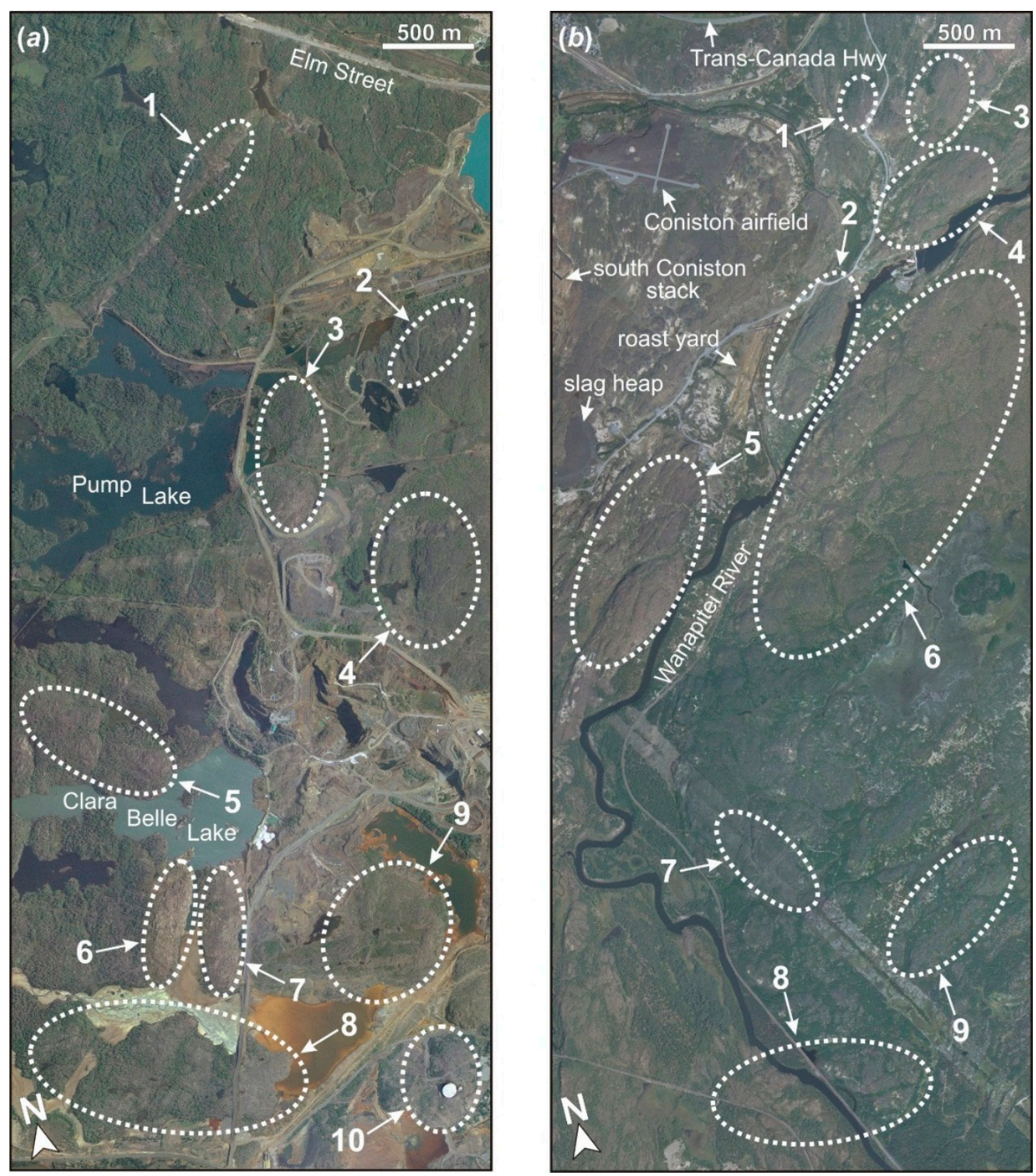

Figure 7. These true-color aerial orthophotos depict selected examples of prominent exposures of coated bedrock (inside dotted ovals) for key parts of the Copper Cliff (a) and Coniston (b) study areas. Depicted areas are outlined in Figure 6. The four Coniston sites depicted in Figure 2 are present in (b) at the south Coniston stack (Figure 2a), Site 2 (Figure 2b), Site 1 (Figure 2c), and the Trans-Canada Highway (Figure 2d).

\section{Hyperion Images}

Hyperspectral images can have considerable utility in the identification and mapping of exposed geological classes [53-59]. The Hyperion sensor, on board the orbiting EO-1 (Earth Observing One) satellite, collects data with a $30 \mathrm{~m}$ pixel size in 242 bands in the visible, near-infrared, and shortwave infrared ranges $[60,61]$. Though Hyperion images are characterized by relatively high levels of noise [59,62-68], they represent important alternatives to datasets generated by orbiting multispectral systems. In numerous case studies, Hyperion images have proven useful in the mapping of lithological and mineralogical classes $[63,64,67,69-76]$. In the Sudbury region, Hyperion images have previously been used in the study of vegetation growth related to land reclamation near smelters [20,77].

Two Hyperion images were evaluated in this study regarding their utility in the discrimination of black rock coatings near the Copper Cliff and Coniston smelters. The footprints of utilized parts 
of these images constrained the extents of associated study areas and are depicted in Figures 1 and 6. The Copper Cliff image was acquired on 23 September 2004, and the Coniston image was acquired on 14 September 2004. Both images were preprocessed through initial deletion of particularly noisy or otherwise unusable bands (original band numbers 1-7, 57-77, and 225-242) and the remaining 198-band images were converted to reflectance using a German Aerospace Center (DLR) radiation model implemented in Version 10 of PCI Geomatica [78]. Additional unusable bands related to atmospheric absorption or image noise were deleted in both images. Parts of the Coniston study area were affected by cloud cover at the time of imaging (Figure $6 c$ ) and were therefore not considered in this study.

\section{Classification Methodology}

This study involved evaluation of the utility of the SAM, feedforward backpropagation neural network, and maximum likelihood algorithms in the discrimination of black rock coatings using image databases derived from Hyperion reflectance data. In order to reduce the negative effects of noise, which produced poor preliminary results, the Hyperion reflectance databases were averaged over nine spectral ranges that were chosen for their relatively low noise levels and relatively high densities of available reflectance values: (1) 400-500 nm; (2) 500-600 nm; (3) 600-700 nm; (4) 700-800 nm; (5) 1550-1650 nm; (6) $1650-1750 \mathrm{~nm}$; (7) $2100-2200 \mathrm{~nm}$; (8) $2200-2300 \mathrm{~nm}$; and (9) $2300-2400 \mathrm{~nm}$ (Figure 8). The produced databases have spectral resolutions that are superior to those typical of multispectral systems such as Landsat Thematic Mapper, particularly within the shortwave infrared.

The SAM algorithm maps the extent of an end-member of interest through quantification of the angle (which acts as a proxy for the resemblance) between the vectors of end-member spectra and those of individual pixel spectra [79]. This routine is widely utilized to classify image databases, in part because it allows users to forgo the definition of a complete set of surface cover classes, which many unmixing and per-pixel classifiers otherwise require $[80,81]$. Thus, users can apply the SAM algorithm to separately classify images on the basis of endmember spectra of individual classes of interest, facilitating studies that are focused on single classes (e.g., rock coatings). The SAM algorithm is less affected by variations in illumination and shading, since this classifier measures angular differences between reflectance vectors rather than differences in overall vector lengths [79]. Endmember spectra used as input to the SAM algorithm can be derived from spectrometer-based measurements of reflectance or can be extracted from images. In this study, the ENVI (Environment for Visualizing Images) implementation of the SAM algorithm was utilized [82], and endmembers were extracted from classified images.

The feedforward backpropagation neural network algorithm relates image values to surface classes on the basis of the magnitudes of weights associated with the links and nodes of a network [81,83-86]. In this study, a standard network geometry was defined with nine nodes in the input layer of the network (with each node associated with one of the nine spectral ranges defined above), nine nodes in each of two intermediate layers, and either six or seven nodes in the output layer (each corresponding to a particular surface class). Weight magnitudes were determined on the basis of training stages involving momentum and learning rate values of 0.9 and 0.1 , respectively. 
a) Copper Cliff
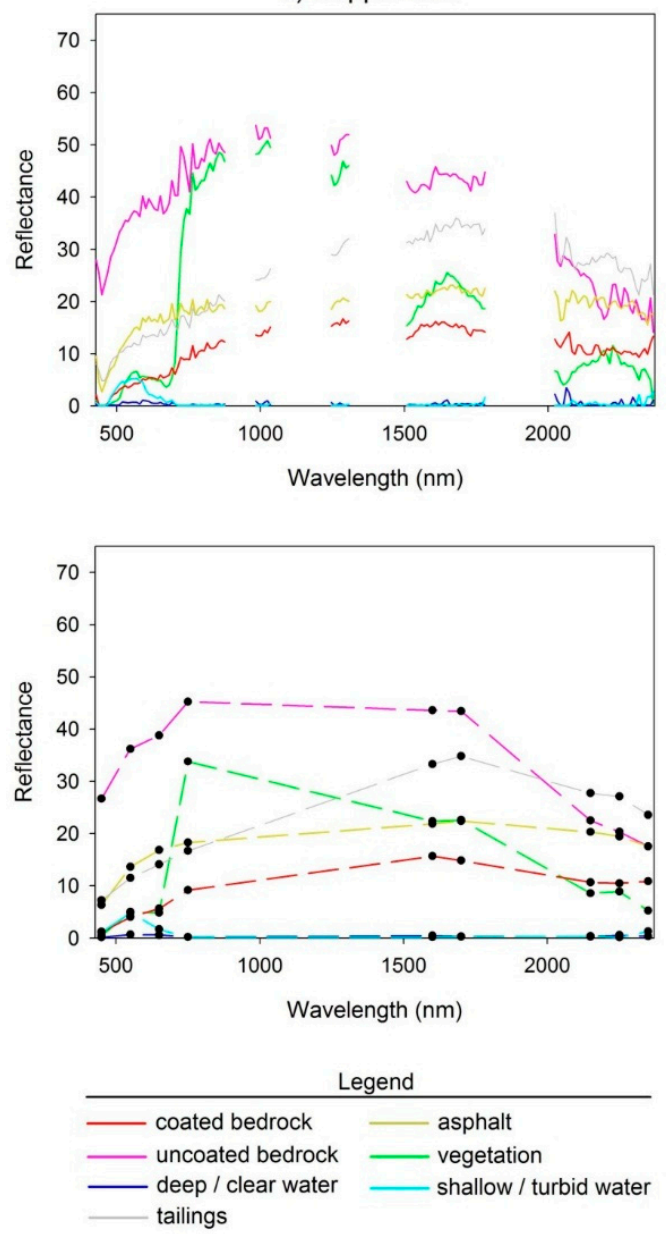

b) Coniston
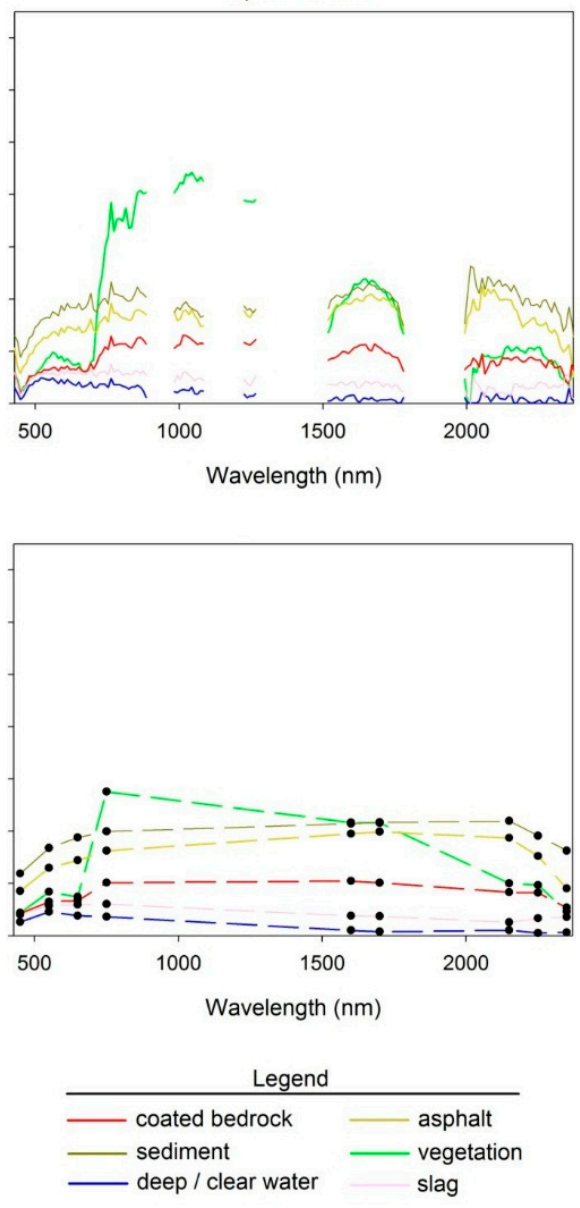

Figure 8. Hyperion-derived reflectance spectra, expressed as percentages, for endmembers of interest in the Copper Cliff (a) and Coniston (b) study areas, over wavelengths of 400 to $2400 \mathrm{~nm}$. Original spectra are given at top and multispectral versions are given at bottom.

The maximum likelihood classifier employs Gaussian probability distributions to parameterize the ranges of image values most typically associated with individual surface cover classes, assigning pixel labels on the basis of the classes that have the highest associated probabilities [81,87]. A null class option can be used to ensure that labels are only assigned where probabilities are relatively high. Under this option, the training data of each class are used to define a hyperellipsoid that has a surface located three standard deviations from the mean vector of the class; image pixels with values that fall outside the hyperellipsoids of all classes are assigned to the null class during classification [78]. In this study, maximum likelihood classifications were performed both with and without a null class.

Classification outcomes were evaluated based on qualitative and quantitative comparisons between predicted and actual distributions of exposures of this class and other common surface classes. Test pixels utilized for non-water classes in the Copper Cliff study area included 477 coated bedrock pixels, 534 tailings pixels, 341 asphalt pixels, 771 vegetation pixels, and 104 uncoated bedrock pixels. Test pixels utilized for non-water classes in the Coniston study area included 329 coated bedrock pixels, 235 asphalt pixels, 236 slag pixels, 431 sediment pixels, and 1344 vegetation pixels. Aspects of the qualitative evaluation of classification outcomes were conducted in consultation with true-color aerial orthoimages of key parts of the study areas (Figure 7), which were acquired for the City of Greater Sudbury in July of 2003. Visual analysis of these orthoimages helped to extend information collected in situ regarding the distribution of exposures of coated bedrock, and assisted in the compilation of appropriate test pixels for this study. 


\section{Results}

Classification outcomes are presented in Figures 9-12 and Tables 1 and 2. SAM-based maps of a range of surface cover classes, including the coated bedrock class, are given in Figure 9 for the Copper Cliff and Coniston study areas. In each map, surface classes are individually represented by superimposed colored masks that depict predicted spatial distributions for optimum spectral angles. From uppermost layer to bottommost layer, the Copper Cliff masks consist of the following: coated bedrock (maximum angle $=0.08$ radians), uncoated bedrock ( 0.2 radians), vegetation (0.3 radians), shallow / turbid water (0.5 radians), and deeper/clear water (0.4 radians), tailings (0.12 radians), and asphalt (0.08 radians) (Figure 9a,b). From uppermost layer to bottommost layer, the Coniston masks consist of the following: coated bedrock (maximum angle $=0.1$ radians), vegetation (0.2 radians), slag (0.15 radians), water (0.6 radians), sediment (0.15 radians), and asphalt (0.15 radians) (Figure $9 \mathrm{c})$. Associated quantitative results of relevance to the success of discrimination of coated bedrock are presented in Tables 1 and 2.
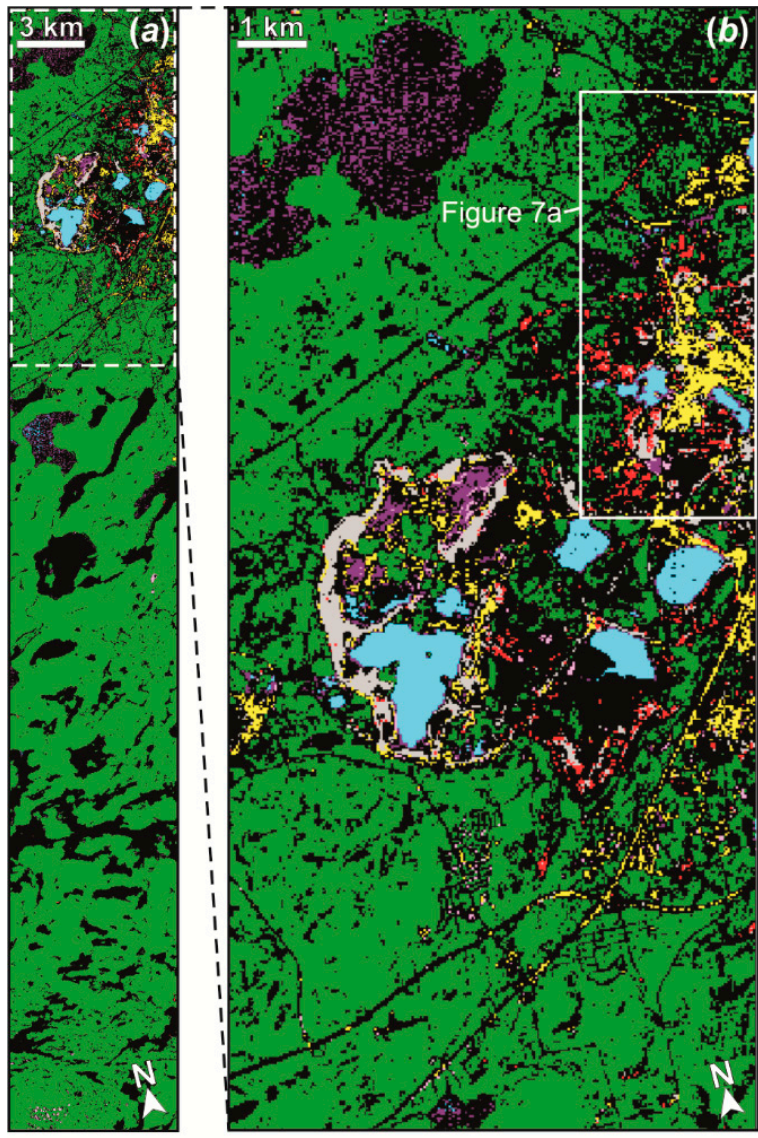

Legend

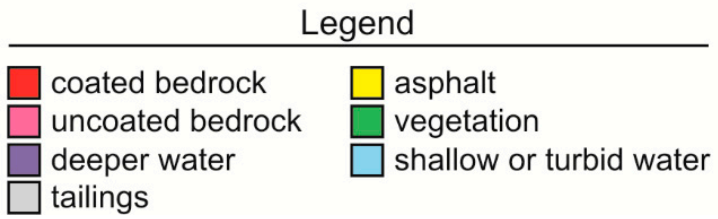

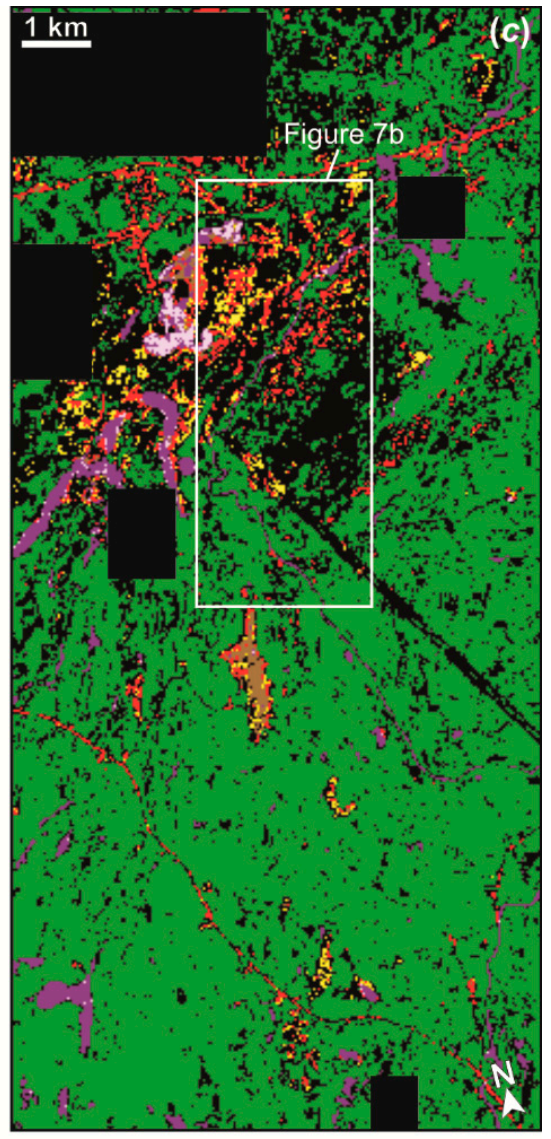

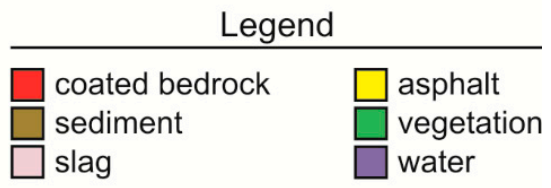

Figure 9. Maps of black coatings and other classes of interest for areas near the Copper Cliff $(\mathbf{a}, \mathbf{b})$ and Coniston (c) smelters, based on SAM classification of the nine-channel multispectral databases generated from Hyperion images. Areas affected by cloud cover in the Coniston study area are masked by black rectangles. Image footprints and smelter stack locations are given in Figure 1. Selected lakes and other landmarks are labeled in Figures 6 and 7. 

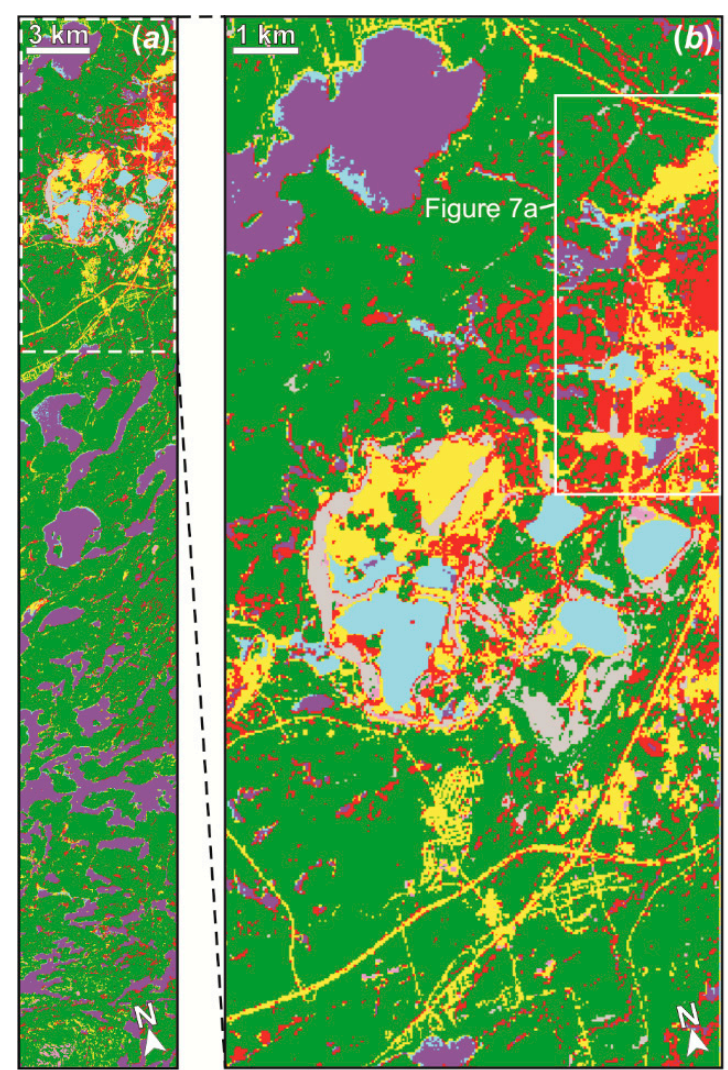

Legend

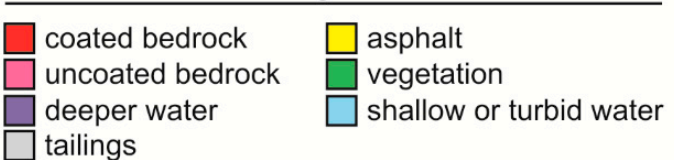

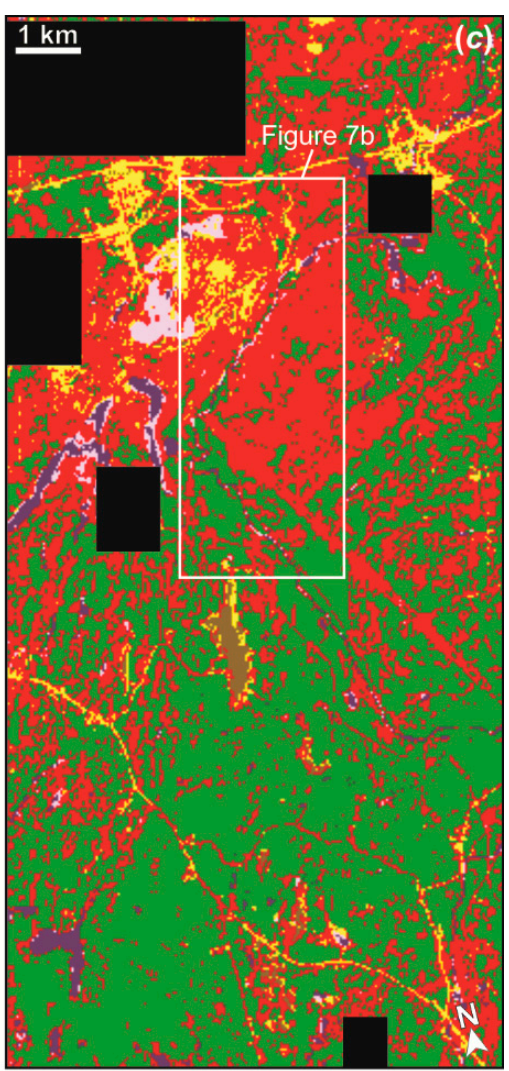

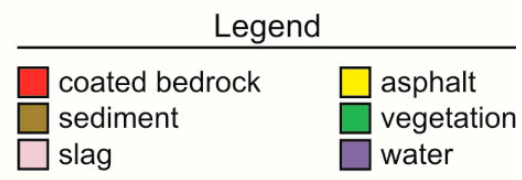

Figure 10. Maps of black coatings and other classes of interest for areas near the Copper Cliff $(\mathbf{a}, \mathbf{b})$ and Coniston (c) smelters, based on neural network classification of the nine-channel multispectral databases generated from Hyperion images. Areas affected by cloud cover in the Coniston study area are masked by black rectangles. Image footprints and smelter stack locations are given in Figure 1. Selected lakes and other landmarks are labeled in Figures 6 and 7.

Table 1. Spectral angle mapper (SAM), neural network (NN), and maximum likelihood (ML) results for the Copper Cliff study area (Figures 9-12). A: proportion of test pixels correctly classified (bold) or misclassified as coated bedrock (errors of commission). B: proportion of coated bedrock test pixels misclassified as uncoated classes (errors of omission).

\begin{tabular}{ccccccccc}
\hline \multirow{2}{*}{ Class } & \multicolumn{2}{c}{ SAM } & \multicolumn{2}{c}{ NN } & \multicolumn{2}{c}{ ML (No Null Class) } & \multicolumn{2}{c}{ ML (With Null Class) } \\
\cline { 2 - 8 } & A & B & A & B & A & B & A & B \\
\hline coated bedrock & $\mathbf{3 5 . 7} \%$ & - & $\mathbf{8 4 . 9 \%}$ & - & $\mathbf{9 3 . 7 \%}$ & - & $\mathbf{6 9 . 8} \%$ & - \\
uncoated bedrock & $0.0 \%$ & $0.0 \%$ & $0.0 \%$ & $0.0 \%$ & $2.0 \%$ & $0.0 \%$ & $0.0 \%$ & $0.0 \%$ \\
asphalt & $0.6 \%$ & $0.2 \%$ & $20.4 \%$ & $1.5 \%$ & $30.2 \%$ & $1.5 \%$ & $5.6 \%$ & $0.0 \%$ \\
tailings & $7.7 \%$ & $25.7 \%$ & $0.6 \%$ & $4.0 \%$ & $6.9 \%$ & $1.0 \%$ & $0.0 \%$ & $0.2 \%$ \\
vegetation & $0.0 \%$ & $2.5 \%$ & $0.0 \%$ & $9.6 \%$ & $0.4 \%$ & $3.8 \%$ & $0.0 \%$ & $0.4 \%$ \\
water (clear) & $0.0 \%$ & $0.0 \%$ & $0.0 \%$ & $0.0 \%$ & $0.0 \%$ & $0.0 \%$ & $0.0 \%$ & $0.0 \%$ \\
water (turbid) & $0.0 \%$ & $0.0 \%$ & $0.0 \%$ & $0.0 \%$ & $0.0 \%$ & $0.0 \%$ & $0.0 \%$ & $0.0 \%$ \\
\hline
\end{tabular}


Table 2. Spectral angle mapper (SAM), neural network (NN), and maximum likelihood (ML) results for the Coniston study area (Figures 9-12). A: proportion of test pixels correctly classified (bold) or misclassified as coated bedrock (errors of commission). B: proportion of coated bedrock test pixels misclassified as uncoated classes (errors of omission).

\begin{tabular}{ccccccccc}
\hline \multirow{2}{*}{ Class } & \multicolumn{2}{c}{ SAM } & \multicolumn{2}{c}{ NN } & \multicolumn{2}{c}{ ML (No Null Class) } & \multicolumn{2}{c}{ ML (With Null Class) } \\
\cline { 2 - 9 } & A & B & A & B & A & B & A & B \\
\hline coated bedrock & $\mathbf{1 9 . 5 \%}$ & - & $\mathbf{9 7 . 9} \%$ & - & $\mathbf{9 7 . 9} \%$ & - & $\mathbf{6 9 . 3} \%$ & - \\
asphalt & $59.2 \%$ & $19.5 \%$ & $16.3 \%$ & $2.1 \%$ & $14.5 \%$ & $2.1 \%$ & $0.4 \%$ & $0.3 \%$ \\
slag & $1.7 \%$ & $0.0 \%$ & $0.8 \%$ & $0.0 \%$ & $24.6 \%$ & $0.0 \%$ & $0.0 \%$ & $0.0 \%$ \\
sediment & $7.7 \%$ & $0.9 \%$ & $1.4 \%$ & $0.0 \%$ & $0.5 \%$ & $0.0 \%$ & $0.0 \%$ & $0.0 \%$ \\
vegetation & $0.0 \%$ & $0.3 \%$ & $4.2 \%$ & $0.0 \%$ & $3.4 \%$ & $0.0 \%$ & $0.8 \%$ & $0.0 \%$ \\
water & $0.0 \%$ & $0.0 \%$ & $0.0 \%$ & $0.0 \%$ & $0.0 \%$ & $0.0 \%$ & $0.0 \%$ & $0.0 \%$ \\
\hline
\end{tabular}
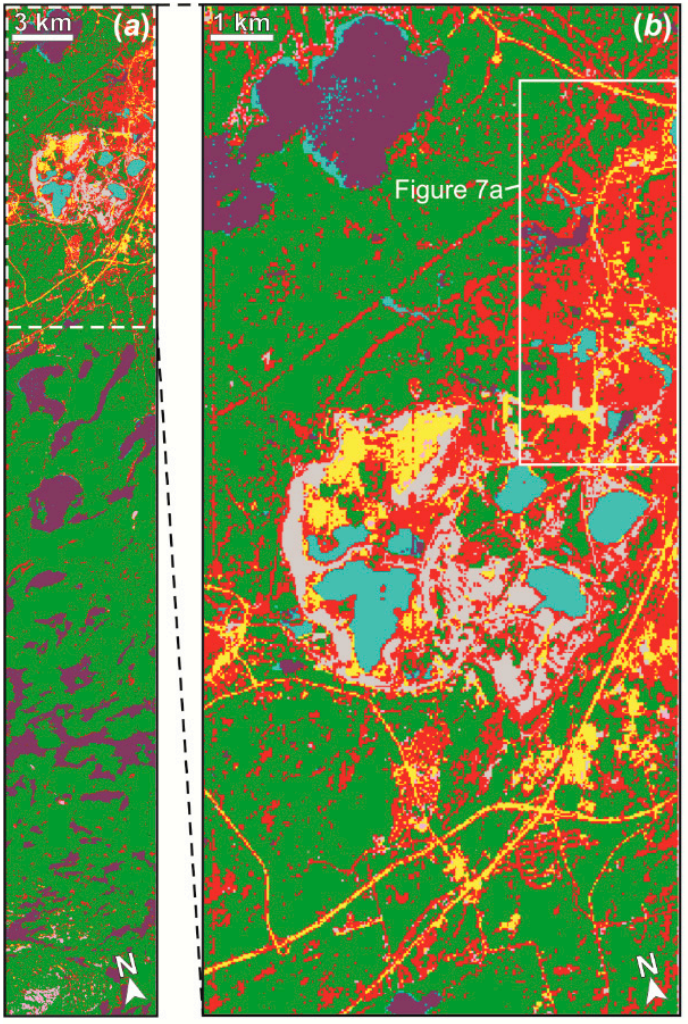

Legend

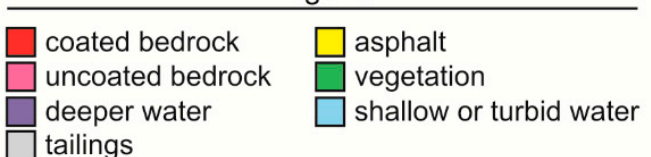

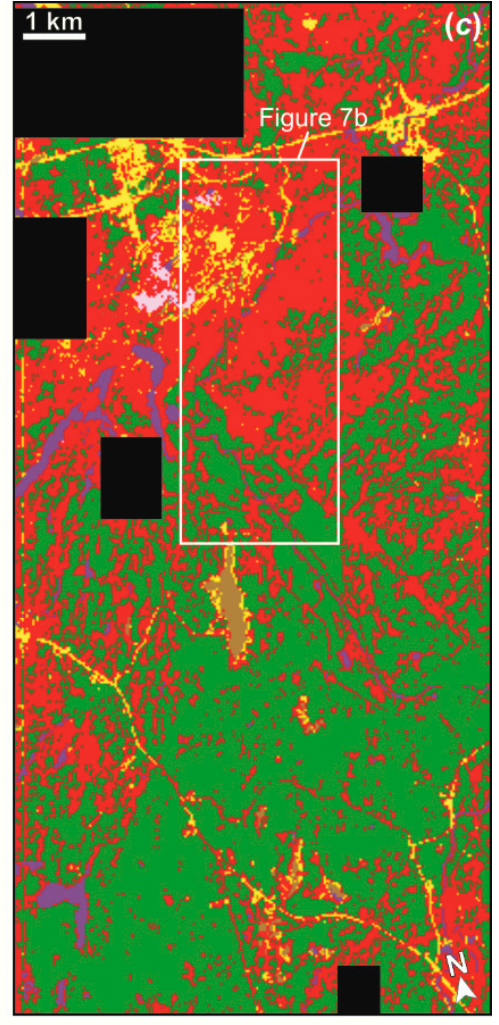

Legend

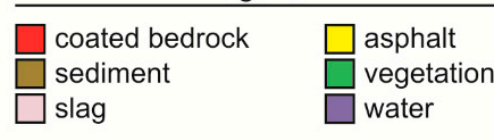

Figure 11. Maps of black coatings and other classes of interest for areas near the Copper Cliff $(\mathbf{a}, \mathbf{b})$ and Coniston (c) smelters, based on maximum likelihood classification (no null class) of the nine-channel multispectral databases generated from Hyperion images. Areas affected by cloud cover in the Coniston study area are masked by black rectangles. Image footprints and smelter stack locations are given in Figure 1. Selected lakes and other landmarks are labeled in Figures 6 and 7.

For the coated bedrock class, spectral angles greater than $\sim 0.8$ to 0.1 radians resulted in widespread confusion with uncoated classes, and optimum results for the Copper Cliff and Coniston study areas are correspondingly presented in Figure 9 for these spectral angles. Overall, only 35.7\% and 19.5\% of coated bedrock test pixels are correctly identified as coated in the SAM-based discrimination of the 
coated bedrock class for the Copper Cliff and Coniston study areas, respectively. Confusion is greatest in these classifications between the coated bedrock class and the asphalt and tailings classes. Most notably, $25.7 \%$ of coated bedrock test pixels in the Copper Cliff study area are misclassified as tailings, and $59.2 \%$ of asphalt test pixels in the Coniston study area are misclassified as coated bedrock. The uncoated bedrock class is not widely present in the Coniston study area at the $30 \times 30 \mathrm{~m}$ pixel size of Hyperion data, and thus misclassifications related to exposed uncoated bedrock could not be usefully assessed. Overall, the SAM-produced classification results are characterized for both study areas by relatively low proportions of coated bedrock test pixels correctly classified, and by problematic confusion between the coated bedrock class and the asphalt and tailings classes.
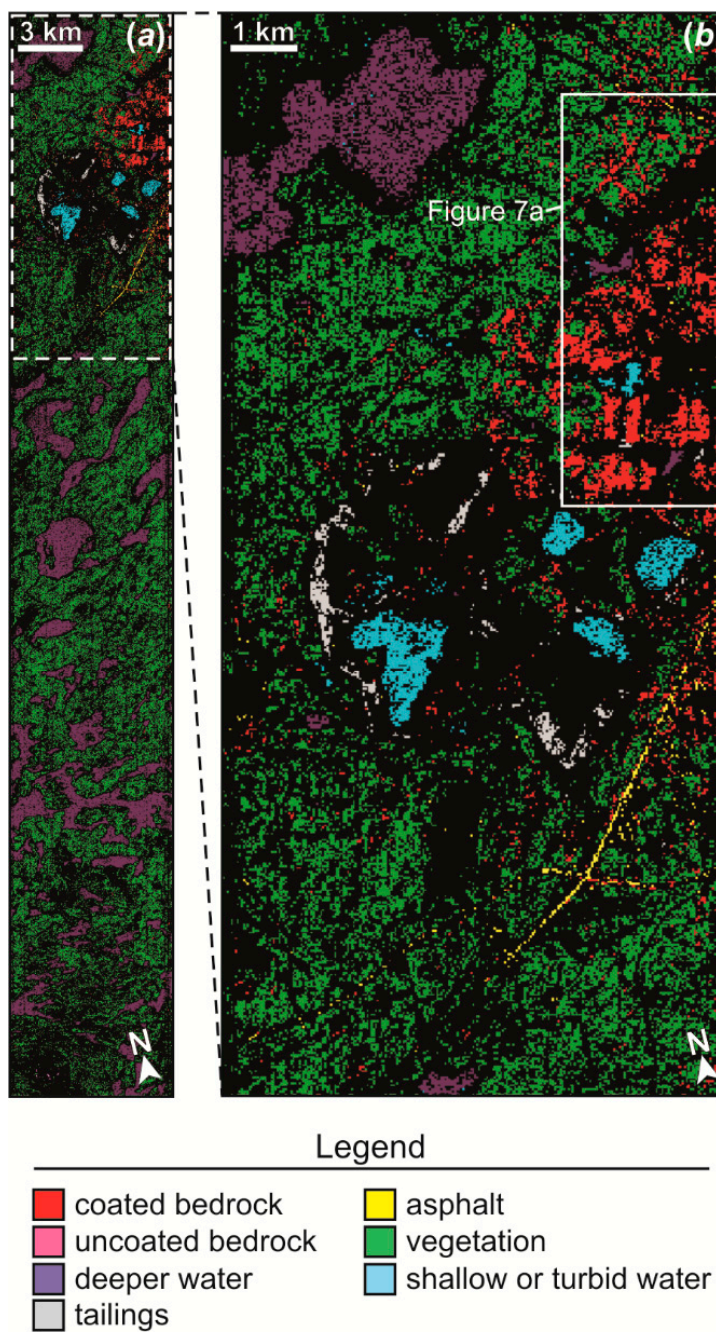
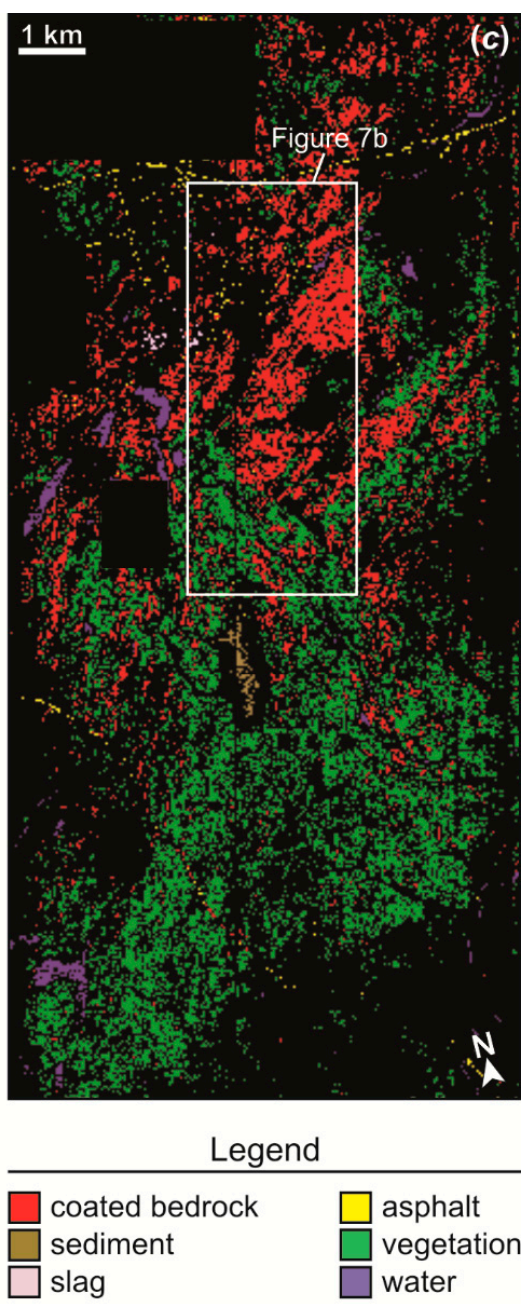

Figure 12. Maps of black coatings and other classes of interest for areas near the Copper Cliff $(\mathbf{a}, \mathbf{b})$ and Coniston (c) smelters, based on maximum likelihood classification (with null class) of the nine-channel multispectral databases generated from Hyperion images. The null class is depicted in black. Areas affected by cloud cover in the Coniston study area are masked by black rectangles. Image footprints and smelter stack locations are given in Figure 1. Selected lakes and other landmarks are labeled in Figures 6 and 7.

Maps of black rock coatings generated by the neural network classifier are given in Figure 10, and associated quantitative results of relevance to the success of discrimination of coated bedrock are given in Tables 1 and 2. The proportions of coated bedrock test pixels correctly classified by the neural network are $84.9 \%$ and $97.9 \%$ for the Copper Cliff and Coniston study areas, respectively. However, these high values are problematically associated with confusion involving the asphalt class, with 
$20.4 \%$ of asphalt test pixels misclassified as coated bedrock in the Copper Cliff study area, and with $16.3 \%$ of asphalt test pixels misclassified as coated bedrock in the Coniston study area. Relatively minor confusion with the vegetation class is also present, with $9.6 \%$ of coated bedrock test pixels in the Copper Cliff study area misclassified as vegetation, and with $4.2 \%$ of vegetation test pixels in the Coniston study area misclassified as coated bedrock.

Maps of black rock coatings generated by the maximum likelihood classifier are given in Figures 11 and 12. The proportion of coated bedrock test pixels correctly classified by the maximum likelihood classifier without null class are 93.7\% and 97.9\% (Figure 11; Tables 1 and 2). As with the neural network results, however, these high values are associated with notable confusion involving uncoated classes including asphalt, slag, and tailings. In particular, $30.2 \%$ of asphalt test pixels and $6.9 \%$ of tailings test pixels were misclassified as coated bedrock in the Copper Cliff study area, and $24.6 \%$ of slag test pixels and $14.5 \%$ of asphalt test pixels were misclassified as coated bedrock in the Coniston study area. Importantly, the use of a null class in maximum likelihood classifications was effective in eliminating most confusion between coated and uncoated materials (Figure 12; Tables 1 and 2). Though the proportions of coated bedrock test pixels correctly classified using the null class are only $69.8 \%$ and $69.3 \%$ for the Copper Cliff and Coniston study areas, respectively, the only notable confusion with the coated bedrock class is related to the $5.6 \%$ of asphalt test pixels misclassified as coated bedrock in the Copper Cliff study area. Qualitatively, the maximum likelihood results generated using a null class are noteworthy for their highlighting of exposures of coated bedrock without substantial confusion with uncoated classes, and for their overall consistency with field-based knowledge of the two study areas.

\section{Discussion}

The SAM-derived maps of black rock coatings generated for the Copper Cliff and Coniston study areas through classification of Hyperion-derived multispectral data (Figure 9) are relatively poor representations of the spatial distribution of the coated bedrock class here. Associated proportions of coated bedrock test pixels correctly classified are low (less than $36 \%$ ), and problematic confusion exists in some parts of the generated maps between the coated bedrock class and surface classes including asphalt and tailings.

The neural network and maximum likelihood classifications of the multispectral database generated from Hyperion data are characterized by relatively high proportions of coated bedrock test pixels that are correctly classified. In particular, the neural network classifications and maximum likelihood classifications generated without a null class are associated with proportions that range between $84.9 \%$ and $97.9 \%$. However, these high proportions are associated with notable confusion between the coated bedrock class and classes including asphalt, tailings, slag, and vegetation. Though the maximum likelihood classifications generated using a null class are characterized by proportions of coated bedrock correctly classified of only $\sim 70 \%$, these results are associated with almost no confusion between coated and uncoated classes. These results are consistent with those previously generated from Landsat ETM+ images using the same neural network and maximum likelihood algorithms [8], in which the maximum likelihood classifier with null class was found to produce the most useful maps of coated bedrock in the vicinities of smelters in the Sudbury region.

The confusion typical of classification results in this study between coated bedrock and uncoated materials such as the asphalt and tailings classes is consistent with the similar shapes of reflectance curves that can exist for materials of these types. In particular, fresh asphalt in the Sudbury study area can be characterized by reflectance magnitudes very similar to those of the coated bedrock class across the wavelengths considered here (Figures 5 and 8). Confusion may have been further promoted in SAM classifications by the emphasis of this algorithm on the forms of reflectance spectra rather than on overall albedos [8], allowing classes characterized by higher or lower reflectance values but somewhat flat spectra (e.g., the tailings and sediment classes) to be more likely to be confused with the coated bedrock class. 
The results of both this study and prior research [8] suggest that the per-pixel classification of multispectral images (e.g., Landsat ETM+ images or multispectral datasets produced from Hyperion images) is well suited for the production of useful maps of black rock coatings near smelters. Maximum likelihood classifications are especially useful in the minimization of errors of commission when a null class is specified. Black rock coatings form where the $\mathrm{pH}$ values of rainwater are lowest and where metal-rich and sulfur-bearing materials accumulate [2,3], and maps of the spatial distributions of coatings can therefore provide information that is highly relevant to identification of areas most severely affected by past or ongoing smelter operations. Maps of coating distributions can provide information that is complementary to that which is derived from studies of vegetation loss, and in regions where bedrock is well exposed will provide information that is more directly relevant to smelter emissions than reductions in vegetation cover (the latter of which can occur as a result of a wide range of natural and anthropogenic processes).

Future research will further evaluate the utility of hyperspectral and multispectral image types and associated processing methods in the discrimination and mapping of black bedrock coatings, as part of an effort to advance the development and refinement of remote sensing methods for the detection, mapping, and monitoring of coating-related environmental degradation in the vicinities of base metal smelters. Assessment and improvement of remote sensing methods for detection of black rock coatings near smelters is relevant to broader objectives regarding the detection of acid-sulfate deposits, including those formed in regions of hydrothermal activity and in urban environments with high atmospheric pollution [2]. In these and other settings, improved understanding of the spatial distribution of coatings would allow for more comprehensive investigation into the environmental impacts of emissions, and could additionally be useful in the identification of centers of emission and of prevailing directions of atmospheric transport.

\section{Conclusions}

The utility of Hyperion-derived multispectral databases in the discrimination of smelter-related black rock coatings was evaluated for two study areas in the Sudbury region of Canada. SAM-based classifications involving the use of image-derived spectra are relatively poor, with no greater than $35.7 \%$ of coated bedrock test sites properly identified as such, and with substantial confusion between coated bedrock and uncoated materials including asphalt and mine tailings. The existence of confusion between the coated bedrock class and uncoated classes such as asphalt is consistent with similarities in associated reflectance properties, and confusion with uncoated classes may have been worsened by the lower capacity of the SAM algorithm to use overall albedo to distinguish classes with otherwise similar forms of reflectance curves. The proportions of coated bedrock test pixels correctly classified by a neural network classifier and a maximum likelihood classifier (without null class) range between $84.9 \%$ and $97.9 \%$. However, these high values are associated with substantial confusion between coated bedrock and uncoated classes. Though the use of a null class in maximum likelihood classifications resulted in the identification of only $\sim 70 \%$ of coated bedrock test pixels, it was effective in nearly eliminating confusion between coated and uncoated materials. Qualitatively, the maximum likelihood results generated using a null class are noteworthy for their proper highlighting of exposures of coated bedrock, and for their overall consistency with field-based knowledge of the two study areas. Though challenges remain, the results of this study confirm the potential of remote sensing methods for use in the worldwide monitoring of coating-related environmental degradation in the vicinities of base metal smelters.

Acknowledgments: Michael Schindler was supported by a grant from the Natural Sciences and Engineering Research Council of Canada.

Author Contributions: David Leverington conducted fieldwork and sample collection in the Sudbury region, generated all image classifications, evaluated classification results, and wrote the initial manuscript. Michael Schindler conducted fieldwork and sample collection in the Sudbury region, characterized the 
geochemistry of local rock coatings, contributed to the evaluation of classification results, and assisted in preparation of the final manuscript.

Conflicts of Interest: The authors declare no conflict of interest.

\section{References}

1. Schindler, M.; Durocher, J.; Abdu, Y.; Hawthorne, F.C. Hydrous silica coatings: Occurrence, speciation of metals, and environmental significance. Environ. Sci. Technol. 2009, 43, 8775-8780. [CrossRef] [PubMed]

2. Mantha, N.M.; Schindler, M.; Kyser, T.K. Silica and sulfate-bearing rock coatings in smelter areas: Part II. Forensic tools for atmospheric metal(loid)-and sulfur-isotope compositions. Geochim. Cosmochim. Acta 2012, 90, 221-241. [CrossRef]

3. Mantha, N.M.; Schindler, M.; Murayama, M.; Hochella, M.F., Jr. Silica-and sulfate-bearing rock coatings in smelter areas: Products of chemical weathering and atmospheric pollution I. Formation and mineralogical composition. Geochim. Cosmochim. Acta 2012, 85, 254-274. [CrossRef]

4. Caplette, J.; Schindler, M.; Kyser, T.K. The black rock coatings in Rouyn-Noranda, Quebec: Fingerprints of historical smelter emissions and the local ore. Can. J. Earth Sci. 2015, 52, 952-965. [CrossRef]

5. Schiffman, P.; Zierenberg, R.; Marks, N.; Bishop, J.L.; Dyar, M.D. Acid-fog deposition at Kilauea volcano: A possible mechanism for the formation of siliceous-sulfate rock coatings on Mars. Geology 2006, 34, 921-924. [CrossRef]

6. Chemtob, S.M.; Jolliff, B.L.; Rossman, G.R.; Eiler, J.M.; Arvidson, R.E. Silica coatings in the Ka'u Desert, Hawaii, a Mars analog terrain: A micromorphological, spectral, chemical, and isotopic study. J. Geophys. Res. 2010, 115, E04001. [CrossRef]

7. Marcucci, E.C.; Hynek, B.M.; Kierein-Young, K.; Rogers, K.L. Visible-near-infrared reflectance spectroscopy of volcanic acid-sulfate alteration in Nicaragua: Analogs for early Mars. J. Geophys. Res. 2013, 118, 2213-2233. [CrossRef]

8. Malcolm, K.J.; Leverington, D.W.; Schindler, M. A Landsat-based study of black rock coatings proximal to base metal smelters, Sudbury, Ontario, Canada. Int. J. Remote Sens. 2015, 36, 3932-3960. [CrossRef]

9. Dill, H.G. The "chessboard" classification scheme of mineral deposits: Mineralogy and geology from aluminum to zirconium. Earth Sci. Rev. 2010, 100, 1-420. [CrossRef]

10. Rousell, D.H.; Meyer, W.; Prevec, S.A. 2002, Bedrock geology and mineral deposits. In The Physical Environment of the City of Great Sudbury; Rousell, D.H., Jansons, K.J., Eds.; Ontario Geological Survey: Sudbury, ON, Canada, 2002; Special Volume 6, pp. 21-55.

11. Saarinen, O.W.; Tanos, W.A. The physical environment of the Sudbury area and its influence on urban development. In The Physical Environment of the City of Great Sudbury; Rousell, D.H., Jansons, K.J., Eds.; Ontario Geological Survey: Sudbury, ON, Canada, 2002; Special Volume 6, pp. 3-18.

12. Davies, B.E. Heavy metal contamination from base metal mining and smelting: Implications for man and his environment. In Applied Environmental Geochemistry; Thornton, I., Ed.; Academic Press: New York, NY, USA, 1983; pp. 425-462.

13. Rieuwerts, J.; Farago, M. Heavy metal pollution in the vicinity of a secondary lead smelter in the Czech Republic. Appl. Geochem. 1996, 11, 17-23. [CrossRef]

14. Schindler, M.; Mantha, N.; Kyser, K.T.; Murayama, M.; Hochella, M.F., Jr. Shining light on black rock coatings in smelter-impacted areas. Geosci. Can. 2012, 39, 148-157.

15. Lanteigne, S.; Schindler, M.; McDonald, A.M.; Skeries, K.; Abdu, Y.; Mantha, N.M.; Murayama, M.; Hawthorne, F.C.; Hochella, M.F., Jr. Mineralogy and weathering of smelter-derived spherical particles in soils: Implications for the mobility of $\mathrm{Ni}$ and $\mathrm{Cu}$ in the surficial environment. Water Air Soil Pollut. 2012, 223, 3619-3641. [CrossRef]

16. Lanteigne, S.; Schindler, M.; McDonald, A. Distribution of metal(loid)s in smelter-derived particulate matter in soils, mineralogical insights into their retention and release in a low-T environment. Can. Mineral. 2014, 52, 453-471. [CrossRef]

17. Coulson, M.G.; Bridges, E.M. The remote sensing of contaminated land. Int. J. Remote Sens. 1984, 5, 659-669. [CrossRef] 
18. Pitblado, J.R.; Gallie, E.A. Remote sensing and geographic information systems: Technologies for mapping and monitoring environmental health. In Restoration and Recovery of an Industrial Region; Gunn, J.M., Ed.; Springer Series on Environmental Management; Springer-Verlag: New York, NY, USA, 1995; pp. $299-311$.

19. Singhroy, V.; Kuhn, F. Remote sensing for characterizing and monitoring of hazardous waste sites-Case studies in Canada and Germany. Int. Arch. Photogram. Remote Sens. 1996, XXXI, Part B7.

20. Champagne, C.M.; Abuelgasim, A.; Staenz, K.; Monet, S.; White, H.P. Ecological restoration from space: The use of remote sensing for monitoring land reclamation in Sudbury. In Proceedings of the 16th International Conference of the Society for Ecological Restoration, Victoria, BC, Canada, 24-26 August 2004.

21. Davidson, J.; Gunn, J. Effects of land cover disturbance on stream invertebrate diversity and metal concentrations in a small urban industrial watershed. Hum. Ecol. Risk Assess. 2012, 18, 1078-1095. [CrossRef]

22. Zubareva, O.N.; Skripal'shchikova, L.N.; Greshilova, N.V.; Kharuk, V.I. Zoning of landscapes exposed to technogenic emissions from the Norilsk Mining and Smelting Works. Russ. J. Ecol. 2003, 34, 415-419. [CrossRef]

23. Pitblado, J.R.; Amiro, B.D. Landsat mapping of the industrially disturbed vegetation communities of Sudbury, Canada. Can. J. Remote Sens. 1982, 8, 17-28. [CrossRef]

24. Allum, J.A.E.; Dreisinger, B.R. Remote sensing of vegetation change near Inco's Sudbury mining complexes. Int. J. Remote Sens. 1987, 8, 399-416. [CrossRef]

25. McCall, J.; Gunn, J.; Struik, H. Photo interpretative study of recovery of damaged lands near metal smelters of Sudbury, Canada. Water Air Soil Pollut. 1995, 85, 847-852. [CrossRef]

26. Tømmervik, H.; Johansen, B.E.; Pedersen, J.P. Monitoring the effects of air pollution on terrestrial ecosystems in Varanger (Norway) and Nikel-Pechenga (Russia) using remote sensing. Sci. Total Environ. 1995, 160-161, 753-767. [CrossRef]

27. Tømmervik, H.; Høgda, K.A.; Solheim, I. Monitoring vegetation changes in Pasvik (Norway) and Pechenga in Kola Penninsula (Russia) using multitemporal Landsat MSS/TM data. Remote Sens. Environ. 2003, 85, 370-388. [CrossRef]

28. Rigina, O. Detection of boreal forest decline with high-resolution panchromatic satellite imagery. Int. J. Remote Sens. 2003, 24, 1895-1912. [CrossRef]

29. Abuelgasim, A.; Chung, C.-J.; Champagne, C.; Staenz, K.; Monet, S.; Fung, K. Use of multi-temporal remotely sensed data for monitoring land reclamation in Sudbury, Ontario (Canada). In 2005 International Workshop on the Analysis of Multi-Temporal Remote Sensing Images; Institute of Electrical and Electronics Engineers: Sydney, Australia, 2005; pp. 229-235.

30. Lévesque, J.; Staenz, K. Monitoring mine tailings revegetation using multitemporal hyperspectral image data. Can. J. Remote Sens. 2008, 34, S172-S186. [CrossRef]

31. Barnett, P.J.; Bajc, A.F. Quaternary geology. In The Physical Environment of the City of Great Sudbury; Rousell, D.H., Jansons, K.J., Eds.; Ontario Geological Survey: Sudbury, ON, Canada, 2002; Special Volume 6, pp. 57-85.

32. Shang, J.; Lévesque, J.; Howarth, P.; Morris, B.; Staenz, K.; Yearwood, P. Preliminary investigation of acid mine drainage detection using casi data, Copper Cliff, Ontario, Canada. In Proceedings of the 21st Canadian Symposium on Remote Sensing, Ottawa, ON, Canada, 21-24 June 1999.

33. Shang, J.; Neville, R.; Staenz, K.; Sun, L.; Morris, B.; Howarth, P. Comparison of fully constrained and weakly constrained unmixing through mine-tailings composition mapping. Can. J. Remote Sens. 2008, 34, S92-S109. [CrossRef]

34. Shang, J.; Morris, B.; Howarth, P.; Lévesque, J.; Staenz, K.; Neville, B. Mapping mine tailings surface mineralogy using hyperspectral remote sensing. Can. J. Remote Sens. 2009, 35, S126-S141. [CrossRef]

35. Richter, N.; Staenz, K.; Kaufmann, H. Spectral unmixing of airborne hyperspectral data for baseline mapping of mine tailings areas. Int. J. Remote Sens. 2008, 29, 3937-3956. [CrossRef]

36. Riaza, A.; Buzzi, J.; García-Meléndez, E.; Vázquez, I.; Bellido, E.; Carrère, V.; Müller, A. Pyrite mine waste and water mapping using Hymap and Hyperion hyperspectral data. Environ. Earth Sci. 2012, 66, 1957-1971. [CrossRef]

37. Percival, J.B.; White, H.P.; Goodwin, T.A.; Parsons, M.B.; Smith, P.K. Mineralogy and spectral reflectance of soils and tailings from historical gold mines, Nova Scotia. Geochem-Explor. Env. A. 2014, 14, 3-16. [CrossRef]

38. Brocoum, S.J.; Dalziel, I.W.D. The Sudbury Basin, the Southern Province, the Grenville Front, and the Penokean Orogeny. Geol. Soc. Am. Bull. 1974, 85, 1571-1580. [CrossRef] 
39. Green, A.G.; Milkereit, B.; Davidson, A.; Spencer, C.; Hutchinson, D.R.; Cannon, W.F.; Lee, M.W.; Agena, W.F.; Behrendt, J.C.; Hinze, W.J. Crustal structure of the Grenville front and adjacent terranes. Geology 1988, 16, 788-792. [CrossRef]

40. Rivers, T.; van Gool, J.A.M.; Connelly, J.N. Contrasting tectonic styles in the northern Grenville province: Implications for the dynamics of orogenic fronts. Geology 1993, 21, 1127-1130. [CrossRef]

41. Dressler, B.O. Sudbury Geological Compilation; Ontario Geological Survey: Sudbury, ON, Canada, 1984.

42. Card, K.D. Metamorphism of the middle Precambrian (Alphebian) of the eastern Southern Province. In Metamorphism in the Canadian Shield; Geological Survey of Canada: Ottawa, ON, Canada, 1978; Paper 78-10, pp. 269-282.

43. Card, K.D. Geology of the Sudbury-Manitoulin Area, Districts of Sudbury and Manitoulin; Report 166; Ontario Geological Survey: Sudbury, ON, Canada, 1978.

44. Meyn, H.D. Geology of Hutton and Parkin Townships; Geological Report 80; Ontario Department of Mines: Sudbury, ON, Canada, 1970.

45. Jackson, S.L.; Fyon, J.A. The Western Abitibi Subprovince in Ontario, In Geology of Ontario; Ontario Geological Survey: Sudbury, ON, Canada, 1991; Special Volume 4, Part 1, pp. 405-482.

46. Easton, R.M. The Grenville Province and the Proterozoic history of central and southern Ontario. In Geology of Ontario; Ontario Geological Survey: Sudbury, ON, Canada, 1991; Special Volume 4, Part 2, pp. 715-904.

47. Winterhalder, K. Early history of human activities in the Sudbury area and ecological damage to the landscape. In Restoration and Recovery of an Industrial Region; Gunn, J.M., Ed.; Springer Series on Environmental Management; Springer-Verlag: New York, NY, USA, 1995; pp. 17-31.

48. Hutchinson, T.C.; Whitby, L.M. Forest ecosystem near the Sudbury smelting region of Canada. Water Air Soil Pollut. 1977, 7, 421-438. [CrossRef]

49. Freedman, B. Environmental Toxicology: The Impacts of Pollution and Other Stresses on Ecosystem Structure and Function; Academic Press: London, UK, 1989; pp. 68-93.

50. Peters, T.H. Rehabilitation of mine tailings: A case of complete ecosystem reconstruction and revegetation of industrially stressed lands in the Sudbury area, Ontario, Canada. In Effects of Pollutants at the Ecosystem Level; Sheehan, P.J., Miller, D.R., Butler, G.C., Bourdeau, P., Eds.; John Wiley and Sons: New York, USA, 1984; pp. 403-421.

51. Peters, T.H. Revegetation of the Copper Cliff tailings area. In Restoration and Recovery of an Industrial Region; Gunn, J.M., Ed.; Springer Series on Environmental Management: New York, NY, USA, 1995; Chapter 9, pp. 123-133.

52. Keller, W.; Heneberry, J.H.; Gunn, J.M. Effects of emission reductions from the Sudbury smelters on the recovery of acid- and metal-damaged lakes. J. Aquat. Ecosyst. Stress Rec. 1999, 6, 189-198. [CrossRef]

53. Goetz, A.F.H.; Vane, G.; Solomon, J.E.; Rock, B.N. Imaging spectroscopy for Earth remote sensing. Science 1985, 228, 1147-1153. [CrossRef] [PubMed]

54. Harris, J.R.; Rogge, D.; Hitchcock, R.; Ijewliw, O.; Wright, D. Mapping lithology in Canada's Arctic: Application of hyperspectral data using the minimum noise fraction transformation and matched filtering. Can. J. Earth Sci. 2005, 42, 2173-2193. [CrossRef]

55. Harris, J.R.; McGregor, R.; Budkewitsch, P. Geological analysis of hyperspectral data over southwest Baffin Island: Methods for producing spectral maps that relate to variations in surface lithologies. Can. J. Remote Sens. 2010, 36, 412-435. [CrossRef]

56. Harris, J.R.; Wickert, L.; Lynds, T.; Behnia, P.; Rainbird, R.; Grunsky, E.; McGregor, R.; Schetselaar, E. Remote predictive mapping 3. Optical remote sensing-A review for remote predictive geological mapping in northern Canada. Geosci. Can. 2011, 38, 49-83.

57. Rogge, D.; Bachmann, M.; Rivard, B.; Feng, J. Spatial sub-sampling using local endmembers for adapting OSP and SSEE for large-scale hyperspectral surveys. IEEE J. Sel. Top. Appl. 2012, 5, 183-195. [CrossRef]

58. Rogge, D.; Rivard, B.; Segl, K.; Grant, B.; Feng, J. Mapping of Ni-Cu-PGE ore hosting ultramafic rocks using airborne and simulated EnMAP hyperspectral imagery, Nunavik, Canada. Remote Sens. Environ. 2014, 152, 302-317. [CrossRef]

59. Van der Meer, F.; van der Werff, H.M.A.; van Ruitenbeek, F.J.A.; Hecker, C.A.; Bakker, W.H.; Noomen, M.; van der Meijde, M.; Carranza, E.J.M.; de Smeth, J.B.; Woldai, T. Multi- and hyperspectral geologic remote sensing: A review. Int. J. Appl. Earth Obs. 2012, 14, 112-128. [CrossRef] 
60. Pearlman, J.; Barry, P.; Segal, C.; Shepanski, J.; Beiso, D.; Carman, S. Hyperion, a space-based imaging spectrometer. IEEE Trans. Geosci. Remote Sens. 2003, 41, 1160-1173. [CrossRef]

61. Middleton, E.M.; Ungar, S.G.; Mandl, D.J.; Ong, L.; Frye, S.W.; Campbell, P.E.; Landis, D.R.; Young, J.P.; Pollack, N.H. The Earth Observing One (EO-1) satellite mission: Over a decade in space. IEEE J. Sel. Top. Appl. 2013, 6, 243-256. [CrossRef]

62. Asner, G.P.; Heidebrecht, K.B. Imaging spectroscopy for desertification studies: Comparing AVIRIS and EO-1 Hyperion in Argentina drylands. IEEE Trans. Geosci. Remote Sens. 2003, 41, 1283-1296. [CrossRef]

63. Kruse, F.; Boardman, J.; Huntington, J. Comparison of airborne hyperspectral data and EO-1 Hyperion for mineral mapping. IEEE Trans. Geosci. Remote Sens. 2003, 41, 1388-1400. [CrossRef]

64. Kruse, F.A.; Perry, S.L.; Caballero, A. District-level mineral survey using airborne hyperspectral data, Los Menucos, Argentina. Ann. Geophys. 2006, 49, 83-92.

65. Hubbard, B.E.; Crowley, J.K. Mineral mapping on the Chilean-Bolivian Altiplano using co-orbital ALI, ASTER, and Hyperion imagery: Data dimensionality issues and solutions. Remote Sens. Environ. 2005, 99, 173-186. [CrossRef]

66. Xu, D.-Q.; Ni, G.-Q.; Jian, L.-L.; Shen, Y.-T.; Li, T.; Ge, S.-L.; Shu, X.-B. Exploring for natural gas using reflectance spectra of surface soils. Adv. Space Res. 2008, 41, 1800-1817. [CrossRef]

67. Kodikara, G.R.L.; Woldai, T.; van Ruitenbeek, F.J.A.; Kuria, Z.; van der Meer, F.; Shepherd, K.D.; van Hummel, G.J. Hyperspectral remote sensing of evaporate minerals and associated sediments in Lake Magadi area, Kenya. Int. J. Appl. Earth Obs. 2012, 14, 22-32. [CrossRef]

68. Rogass, C.; Mielke, C.; Scheffler, D.; Boesche, N.K.; Lausch, A.; Lubitz, C.; Brell, M.; Spengler, D.; Eisele, A.; Segl, K.; Guanter, L. Reduction of uncorrelated striping noise-Applications for hyperspectral pushbroom acquisitions. Remote Sens. 2014, 6, 11082-11106. [CrossRef]

69. Hubbard, B.E.; Crowley, J.K.; Zimbelman, D.R. Comparative alteration mineral mapping using visible to shortwave (0.4-2.4 $\mu \mathrm{m})$ Hyperion, ALI, and ASTER imagery. IEEE Trans. Geosci. Remote Sens. 2003, 41, 1401-1410. [CrossRef]

70. Sgavetti, M.; Pompilio, L.; Meli, S. Reflectance spectroscopy $(0.3-2.5 \mu \mathrm{m})$ at various scales for bulk-rock identification. Geosphere 2006, 2, 142-160. [CrossRef]

71. Gersman, R.; Ben-Dor, E.; Beyth, M.; Avigad, D.; Abraha, M.; Kibreab, A. Mapping of hydrothermally altered rocks by the EO-1 Hyperion sensor, northern Danakil Depression, Eritrea. Int. J. Remote Sens. 2008, 29, 3911-3936. [CrossRef]

72. Khan, S.D.; Jacobson, S. Remote sensing and geochemistry for detecting hydrocarbon microseepages. Geol. Soc. Am. Bull. 2008, 120, 96-105. [CrossRef]

73. Leverington, D.W. Discrimination of geological end members using Hyperion imagery: Preliminary results, Big Bend National Park, Texas. IEEE Geosci. Remote Sens. Symp. 2008, 2, II-1266-II-1269.

74. Leverington, D.W. Discrimination of sedimentary lithologies using Hyperion and Landsat TM data: A case study at Melville Island, Canadian High Arctic. Int. J. Remote Sens. 2010, 31, 233-260. [CrossRef]

75. Bishop, C.A.; Liu, J.G.; Mason, P.J. Hyperspectral remote sensing for mineral exploration in Pulang, Yunnan Province, China. Int. J. Remote Sens. 2011, 32, 2409-2426. [CrossRef]

76. Zhang, T.; Shao, Y.; Gong, H.; Li, L.; Wang, L. Salt content distribution and paleoclimatic significance of the Lop Nur "Ear" feature: Results from analysis of EO-1 Hyperion imagery. Remote Sens. 2014, 6, 7783-7799. [CrossRef]

77. White, H.; Abuelgasim, A. Monitoring environmental remediation: Hyperspectral mapping of re-vegetated areas affected by smelting operations in Sudbury, Canada. In Proceedings of the 2nd Workshop on Hyperspectral Image and Signal Processing: Evolution in Remote Sensing (WHISPERS), IEEE, Reykjavik, Iceland, 14-16 June 2010.

78. PCI. Geomatica 10 Documentation; PCI Geomatics: Richmond Hill, ON, Canada, 2005.

79. Kruse, F.A.; Lefkoff, A.B.; Boardman, J.W.; Heidebrecht, K.B.; Shapiro, A.T.; Barloon, P.J.; Goetz, A.F.H. The Spectral Image Processing System (SIPS) - Interactive visualization and analysis of imaging spectrometer data. Remote Sens. Environ. 1993, 44, 145-163. [CrossRef]

80. Boardman, J.W. Inversion of imaging spectrometry data using singular value decomposition. In Proceedings of the International Geoscience and Remote Sensing Symposium, Vancouver, BC, Canada, 10-14 July 1989; Volume 4, pp. 2069-2072.

81. Richards, J.A. Remote Sensing Digital Image Analysis: An Introduction; Springer: New York, NY, USA, 2012. 
82. Environment for Visualizing Images (ENVI). Exelis, Boulder, USA. Available online: http://www. harrisgeospatial.com/IntelliEarthSolutions/GeospatialProducts/ENVI.aspx (accessed on 30 March 2016).

83. Bishop, C.M. Neural Networks for Pattern Recognition; Oxford University Press: New York, NY, USA, 1995.

84. Gallant, S.I. Neural Network Learning and Expert Systems; MIT Press: Cambridge, MA, USA, 1993.

85. Leverington, D.W.; Moon, W.M. Landsat-TM-based discrimination of lithological units associated with the Purtuniq ophiolite, Quebec, Canada. Remote Sens. 2012, 4, 1208-1231. [CrossRef]

86. Cracknell, M.; Reading, A.M. Geological mapping using remote sensing data: A comparison of five machine learning algorithms, their response to variations in the spatial distribution of training data and the use of explicit spatial information. Comput. Geosci. 2014, 63, 22-33. [CrossRef]

87. Leverington, D.W.; Duguay, C.R. Evaluation of three supervised classifiers in mapping "depth to late-summer frozen ground", central Yukon Territory. Can. J. Remote Sens. 1996, 22, 163-174. [CrossRef]

(C) 2016 by the authors; licensee MDPI, Basel, Switzerland. This article is an open access article distributed under the terms and conditions of the Creative Commons by Attribution (CC-BY) license (http:/ / creativecommons.org/licenses/by/4.0/). 